easily into the other aspects of the philosopher's system, and thus does less to disturb the balance of the system as a whole. In the case of Kant, Buchdahl's revisions of previously standard types of emphasis may be wholly justified; unfortunately, in the case of his lengthy treatment of Descartes, I find less justification. It does not seem to me that he has done justice to the formative influence which Descartes's early scientific inquiries seem to have had on his doctrine of method, nor has he shown how Descartes himself later conceived his system of the sciences to be related to basic metaphysical truths. Fach of these approaches would have been wholly consonant with the interpretation of Descartes which Buchdahl does in fact offer, and together they would have added balance and depth to what he did say. In this case, I suspect, it was Buchdahl's use of "the propositional link" as a unify. ing theme that got in his way. It is, however, both unfair and ungenerous to complain of one chapter (in which others may none the less find merit) when Buchdahl's book as a wholo is as enlightening as it is.

MaUrice Mandelbaum

\section{ARISTOTLE AND CHANGE}

\section{Aristotle's Physics}

Translated with Commentaries and Glossary by Hippo. crates G. Apostle. Pp. xi +386. (Indiana University Press: Bloomington and London, November 1969.) $119 s$ boards ; $36 s$ paper.

For Aristotle the most fundamental feature of the natural world is the occurrence of change, an attitude probably inherited from Plato, who contrasts (for example, Timaeus 27-28) the visible world of "becoming" with the realm of "being" of the Forms. Correspondingly, the most fundamental part of natural philosophy is for him the inquiry into change as such, which he calls "physics". Thus Aristotle's physies is a much narrower discipline than physics in the modern sense: it is concerned with the factors involved in a change, with the definition of change, and with whatever other things need to be understood for a proper understanding of change (for example, place, time, the infinite). Also, it has to eliminate the paradoxes of motion proposed by Zeno. A major problem for Aristotle is to establish that change will never cease in our world, and the last and longest book of the Physics is devoted to this single problem.

A major difficulty in making Aristotle available to the non-specialist in ancient philosophy lies in his technical vocabulary. The temptation of making a flexible translation into "easily understandable" English has to be resisted; yet the approach of choosing a constant, but somewhat arbitrary, translation for each technical term also has its problems. Professor Apostle adopts the most satisfactory solution of translating in a largely constant manner, but indicating in ample glossaries, for example, that "motion" (the conventional translation of kinesis) regularly covers more kinds of change than just change of place. The non-classicist will also find Professor Apostle's commentary very helpful, because it is devoted largely to supplying omitted steps in Aristotle's argument and background information about the doctrines of other Greek philosophers to which Aristotle simply refers.

One small criticism of this generally useful English version is that Apostle assumes that the prime movers of the Metaphysics and of Physics VIII are identical, and this assumption is occasionally reflected in his translation. The doubtfulness of this identity was shown by Nolte (Het godsbegrip bei Aristoteles): for example, the prime mover of Physics VIII is presumably the unmoved part of a self-moving thing, perhaps the soul of the outermost heaven, but the God of the Metaphysics is an object of love of the outermost heaven. Moreover (as Nolte overlooked), the short treatise On the Motion of Animals reads very well as a severe critique of the conclusions of Physics VIII followed by a short sketch of the Metaphysics approach. This minor qualification should not, however, deter anybody from using Apostle's book.

MaLCOLM F. LowE

\section{THREE MEN OF SCIENCE}

\section{Partners in Science}

Edited by Eric Robinson and Douglas McKie. (Letters of James Watt and Joseph Black.) Pp. xvi+502. (Constable: London, January 1970.) $84 s$.

THE 260 letters in this collection document the friendship between three of the most important Scottish men of science of the eighteenth century: Joseph Black, James Watt and John Robison. All known letters between Black and Watt and those between Watt and Robison are reproduced in full, together with a few other relevant letters and documents, of which the most valuable is undoubtedly a previously unpublished notebook containing (among other things) Watt's record of his littleknown experimental work on the latent heat of condensation of steam. A small number of the letters in this volume have been published before, but most of them are printed here for the first time.

Black, Watt and Robison first met in Glasgow about 1757, when they were respectively university professor, instrument-maker, and undergraduate. Regular correspondence between Black and Watt began some ten years later, soon after Black's departure for Edinburgh, and, with Watt settled in Birmingham from 1774, continued unabated until Black died in 1799 . Robison seems never to have inspired either Black or Watt with quite the affection that these two felt so intensely for each other, but he was a loyal friend (who devoted much labour to the editing of Black's posthumous Lectures on the Elements of Chemistry) and he corresponded vigorously with Watt, especially in the last ten years of his life, to 1805 .

Happily, the period covered by the correspondence spans just those crucial years in which the industrial revolution came to maturity, and this book will therefore be an obvious quarry for historians in many fields. Economic and social historians, for example, will welcome the new light that is thrown on the problems of raising capital and of recruiting and training technical and managerial staff. The use of patent law to preserve important monopolies will also attract attention, for Watt's activities in preparation for his legal proceedings against the Hornblowers are particularly well documented here. The historian of science, too, will need no reminding that it was during the period of the correspondence that the new French chemistry supplanted the old chemistry of phlogiston to which Black and the Scottish chemists had long been firmly committed. According to Robison, Black pondered for several days on first hearing of Lavoisier's chemistry and, encouraged by James Hutton, he even toyed with the idea of resisting; but then, much to Robison's disgust, he meekly went over to the new doctrines "more like a pupil than a brother philosopher", and "patched" his lectures to accommodate Lavoisier's views. We are left to conjecture how effectively Black might have led a rearguard action against the French if he had been in better health at the crucial poriod, if he had been of a more disputatious nature, or if, perhaps more pertinently, he had seen his role as that of a researcher jealous for his own reputation rather than that of the great teacher which ho so obviously was.

Although this book will be of greatest valuo as a standard souree for the scholarly work of historians, it contains much that should commend it to readers with less specialized interests. Certainly there is a solemnity and humourlessness about the exchanges and a somewhat depressing preoccupation on the part of all three corre- 